\title{
Transesophageal access to the cardiac cavities and descending thoracic aorta via echoendoscopy. An experimental study
}

\author{
A. López Martín, M. Pérez-Paredes ${ }^{1}$, P. Esteban, R. Latorre ${ }^{2}$, F. Soria ${ }^{3}$, R. Lima ${ }^{3}$, I. Delgado ${ }^{3}$, \\ A. Ruiz $\operatorname{Ros}^{1}$, E. Pérez Cuadrado and L. F. Carballo Álvarez ${ }^{4}$ \\ Sections of Gastroenterology and ${ }^{1}$ Cardiology. "Morales Meseguer" University Hospital. Murcia, Spain. ${ }^{2}$ School of \\ Veterinary. University of Murcia. Spain. ${ }^{3}$ Minimally Invasive Surgery Centre Jesús Usón (MISCJU). Cáceres, Spain. \\ ${ }^{4}$ Department of Digestive Diseases. Virgen de la Arrixaca Hospital. Murcia, Spain
}

\begin{abstract}
Objective: the applications of endoscopic ultrasonography have diversified over recent years. The possibility of reaching cardiac territory has been successfully explored in experimental models, opening up a new field of possibilities for diagnostic and therapeutic interventions that were unthinkable until very recently. The aims set out in this study are to evaluate cardiac anatomy, its approach, the safety of the experimental procedure and the resulting morphological and histological changes after the procedure.

Material and methods: the study has been performed on two adult pigs. They have undergone different surgical approaches to the cardiac cavities and descending thoracic aorta with excellent results.

Results: different cardiac structures have been identified and operated upon (right auricle, left auricle, left ventricle, cardiac valves), as well as major vessels. The use of contrast, both intracavitary and from a peripheral vein, enabled us to verify the anatomical spaces studied. During the procedures we monitored for arrhythmias, hemodynamic behavior, possibility of infection by obtaining sample hemocultures before and after procedures, and response to punctures.

Conclusions: the present study has enabled us to evaluate access to the heart from the esophageal lumen using endoscopic ultrasonography, with results that are very similar to those described in the current bibliography. However, we offer two novelties: puncture of the right auricle through the interauricular partition and puncture of the descending thoracic aorta, both performed with ease and apparent safety.
\end{abstract}

Key words: Echoendoscopy. Cardiac cavities. Fine-needle puncture. Experimental study.

Received: 25-03-09.

Accepted: 14-05-09.

Correspondence: Aurelio López Martín. Unidad de Aparato Digestivo. Endoscopias. Hospital Universitario Morales Meseguer. C/ Marqués de los Vélez, s/n. 30008 Murcia, Spain.e-mail: aureliolm@gmail.com
López Martín A, Pérez-Paredes M, Esteban P, Latorre R, Soria F, Lima R, Delgado I, Ruiz Ros A, Pérez Cuadrado E, Carballo Álvarez LF. Transesophageal access to the cardiac cavities and descending thoracic aorta via echoendoscopy. An experimental study. Rev Esp Enferm Dig 2009; 101: 601-609.

\section{INTRODUCTION}

Endoscopic ultrasonography (EUS) enables us to precisely explore the area situated between 7 to $10 \mathrm{~cm}$ around the digestive tube. At the height of the mediastinum, this area includes the cardiac structures of which the left auricle and the pulmonary trunk are directly accessible. EUS with fine-needle puncture aspiration (EUSFNPA) has been established as a safe technique with a low complication rate, used for different applications such as obtaining samples from different types of injury, drainage of collections and lesion sclerosis. As a result, it has become a significant technique even outside the circles of gastroenterology (1).

The anatomical connection between the esophagus and the heart has led to the development of transesophageal echocardiography, which is extensively used in clinical practice; interventional applications require linear echoendoscopes (2-4).

One of the most important achievements of modern cardiology is the ability to perform diagnostic and therapeutic techniques which require an invasive or surgical approach via semi-invasive procedures of high clinical performance, which minimize the potential risk or damage to the patient. Numerous techniques, generally intravascular, are performed using this kind of approach in cardiology. Thus, techniques such as coronary graphic and hemodynamic studies, valvuloplasty, myocardial biopsy, drainage of pericardial hemorrhages, or the ablation of accessory vessels by radiofrequency, are common 
practice in this field (5-7). The possibility of adapting new technologies in this field, and of exploring other forms of approximation to the cardiac cavities, other than intra-arterial and intravenous, offer a challenge of great clinical and research interest. The echoendoscopic approach and fine-needle puncture aspiration are well established in digestive and mediastinal injuries, and have been used to both diagnostic and therapeutic ends. However, the possibility of approaching and reaching the cardiac cavities and thoracic aorta with FNPA needles has not yet been studied, though some isolated clinical cases have been communicated and a short test was performed on an experimental animal with good results $(8,9)$.

The aim of this study was to evaluate the viability of the approach to the cardiac cavities from the esophageal lumen, as well as to assess the safety of the technique.

In this study we analyzed the viability of access to different cardiac cavities via transesophageal puncture of the heart, myocardial reactivity to this procedure, morphological and histological changes induced in the punctured structures -esophageal wall, pericardium, left auricle (LA) wall, interauricular partition and the descending thoracic aorta-, and hemodynamic behavior during studies.

\section{MATERIAL AND METHODS}

The study was performed on 2 adult pigs, weighing $50 \mathrm{~kg}$ each, with no known previous pathology (animals 1 and $2)$. The study was performed at the Minimally Invasive Surgery Center Jesús Usón in Cáceres, Spain. The anesthetic preparation and monitoring was run by the veterinary anesthetists from the center.

A careful asepsis of the oral cavity was performed and a general anesthetic was administered after orotracheal intubation and connection to mechanical ventilation. The animals were monitored with continuous ECG, pulsioximetry and arterial pressure. All the work times were recorded with two simultaneous recording systems. The animals fasted for the previous 24 hours.

This activity was approved by the Ethical Committee for animal experimentation of MISCJU and complies with EU Directive 86/609/CEE of November $26^{\text {th }}, 1986$, on the protection of animals used for experimentation and other scientific and teaching goals. This Directive has been incorporated into Spanish laws via the Royal Decree 223/1988 of 14/03, and establishes the norms of the rearing establishments, state governed experimental animal suppliers and users, as well as the authorization for the use of animals in experiments, and the RD $1201 / 2005$, on protection of animals used for experimentation and other scientific ends.

The Ethical Committee was presented with a detailed report of the activity, and a protocol of the interventions to be performed. The animals were given inhaled anesthetics with analgesic control and complete monitoring.
No recommendations were made by the Ethical Committee.

1. Ultrasounds and instrumental material. The procedures were performed using a Pentax linear fiber echoendoscope FG 32 UA with optical adapter for video, joined to a Hitachi EUB 6500 echographic console. Cook 19 and $22 \mathrm{G}$ puncture needles, radiolucid guides and Sonovue ${ }^{\circledR}$ ultrasound contrast were used. The interventions were only performed under echoendoscopic control, with injection of an echographic contrast agent to make certain segments clearer.

2. Anesthetic procedure. The animals were given inhaled anesthetics (sevofluorane) with intraoperatory analgesic control (ketamine, ketorolac, diazepam).

Anesthetic monitoring

- Cardiac and hemodynamic parameters: cardiac frequency, electrocardiogram, non-invasive arterial pressure.

- Ventilatory parameters: respiratory frequency, pulsioximetry, pressure in the airways, tidal volume and minute volume, $\mathrm{CO}_{2}$ inhaled and exhaled, $\mathrm{O}_{2}$ inhaled and exhaled, capnogram, plethysmogram, sevofluorane inhaled and exhaled.

After the animals' recovery they were kept for 10 days in their individual cubicles. During the animals' hospitalization they were checked every day by the veterinary staff (appetite checked, temperature taken, auscultation).

After this monitoring period the animals were sacrificed and a necropsy was performed, in which macroscopic lesions in the thoracic cavity were evaluated and samples from viscera were sent off for microscopic examination.

3. Laboratory study. In order to determine potential iatrogeny on the cardiac muscle, as well as the possibility of infection, the following parameters were measured before and after the procedure and at 10 days: hemoculture (CK, myoglobin, troponin T, CK-MB), CPK-mb, troponin I, myosin, hemogram, and general biochemical parameters.

4. Echoendoscopic study. The procedure began with the oral introduction of the linear echoendoscope, firstly performing a detailed identification of the mediastinal area and vascular structures before evaluating the animals' cardiac anatomy. The cardiac structures were then approached from the transesophageal approximation with standard planes described for monoplane probes (10) entering the heart via the left auricle. The anatomical structures closest to the esophagus are the LA, aortic and mitral valves and pulmonary artery trunk. The right cardiac cavities are on the most distal plane. The ultrasound contrast $\left(\right.$ Sonovue ${ }^{\circledast}$ ) administered both by the puncture needle and from a peripheral vein enabled us to view the entrance of the needle into each cavity, and to ensure its precise identification. After passing the echoendoscope 30 to $45 \mathrm{~cm}$ through the esophagus, the puncture needles were introduced into the LV via the LA by advancing a guide line via the $19 \mathrm{G}$ to the LA, and via the mitral valve 
to the LV (animal number 1). The RA was accessed through the interauricular partition as well as the descending thoracic aorta (animal number 2).

\section{RESULTS}

The control of intraoperative hemodynamic alterations was performed by the Coordinator of the Unit of Anesthetics, Resuscitation and Pain Therapy. He is a veterinary doctor with more than 15 years of experience in research with animal models, with a Doctorate from University of Extremadura, his doctoral dissertation being on the pig model for intraoperatory analgesic control; he is also co-founder of the Spanish Association of Veterinary Anesthesiology. There was also a specialist in human cardiology in the same operating theater.

\section{Main findings}

- Animal number 1: the different cardiac structures were identified viewing them in the echocardiographic planes corresponding to the longitudinal sections of the right cavities and of the left cavities, with LV outlet duct and aortic valve (Figs. 1 and 2). The closest and most easily approachable structure from the esophagus was LA. LA was punctured at different angles in search of the most longitudinal axis which would allow the needle to progress towards the left ventricle through the mitral valve. This was easily achieved (Fig. 3).

- Animal number 2: similarly, the normal cardiac anatomy was identified and RA was approached through the interauricular partition once LA had been reached via the adjacent esophagus, using a transversal plane of the

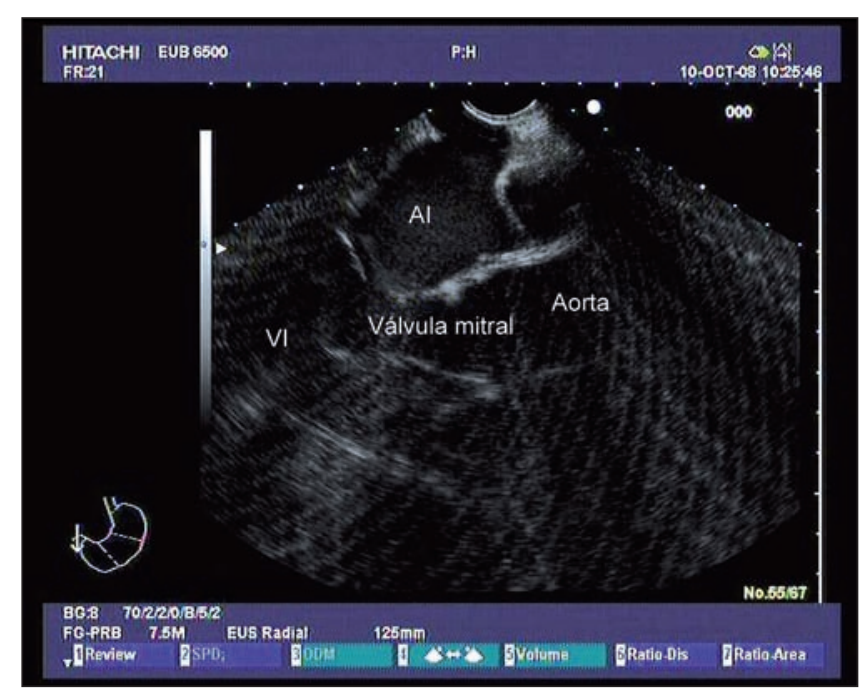

Fig. 1. Different cardiac structures, left auricle (LA), left ventricle (LV), LV outlet duct and aortic valve.

Diferentes estructuras cardiacas, aurícula izquierda (Al), ventrículo izquierdo (VI), tracto de salida de VI y válvula aórtica.

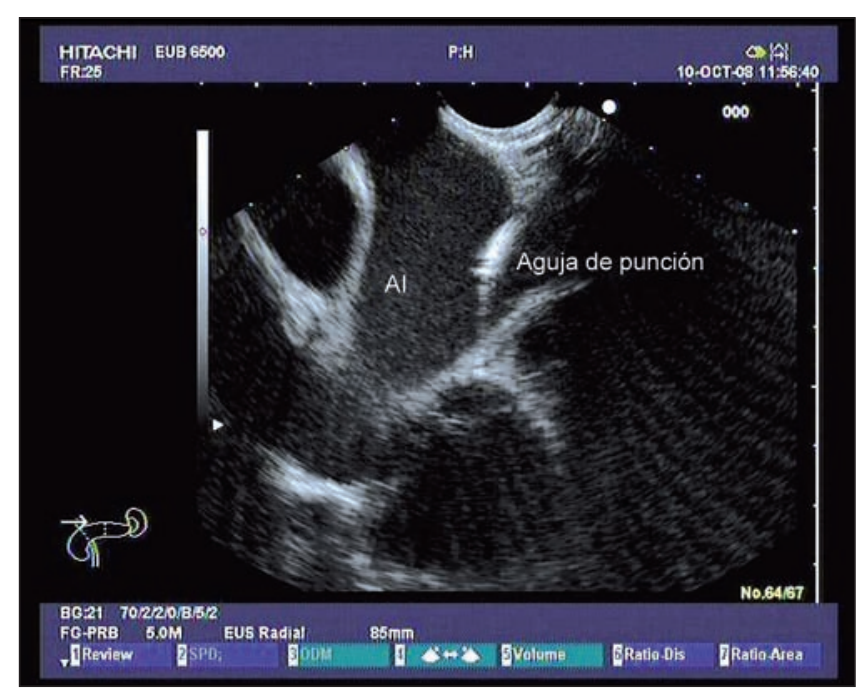

Fig. 2. Puncture of the left auricle.

Punción de aurícula izquierda.

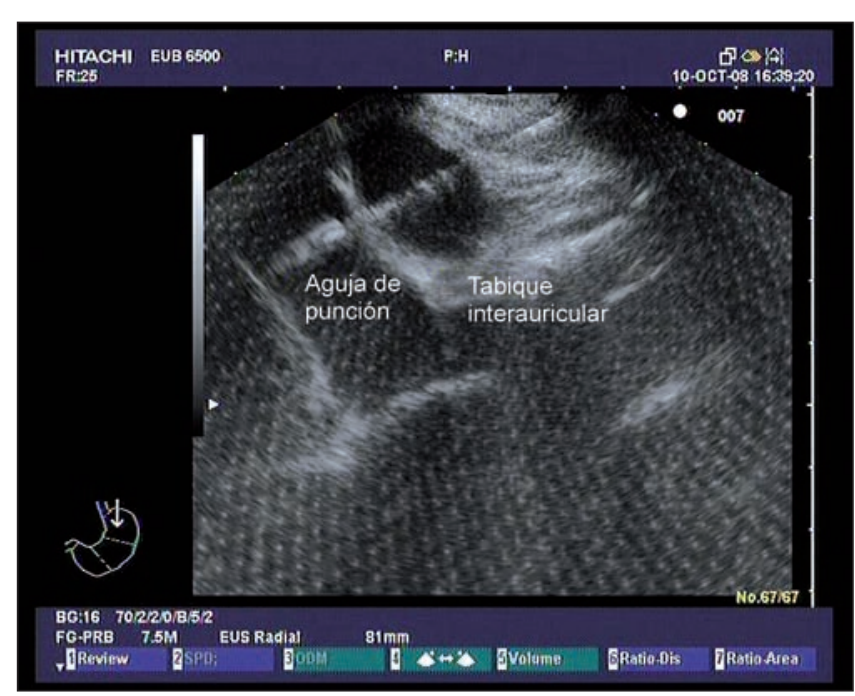

Fig. 3. Puncture of RA.

Punción de $A D$

aortic root with LA, RA and interauricular septum (Fig. 4). No difficulties were encountered in reaching RA, although the partition had to be punctured repeatedly in an attempt to reach the fossa ovalis. From the area of the aortic root the endoscope was turned in a counter-clockwise direction until a horizontal section of the descending aorta was visualized. This vessel was then punctured at different points.

2. Induction of arrhythmias: during the studies no arrhythmias were registered, except a limited number of isolated ventricular extrasystoles without complex forms, before contact of the needle with the left ventricle myocardium. 


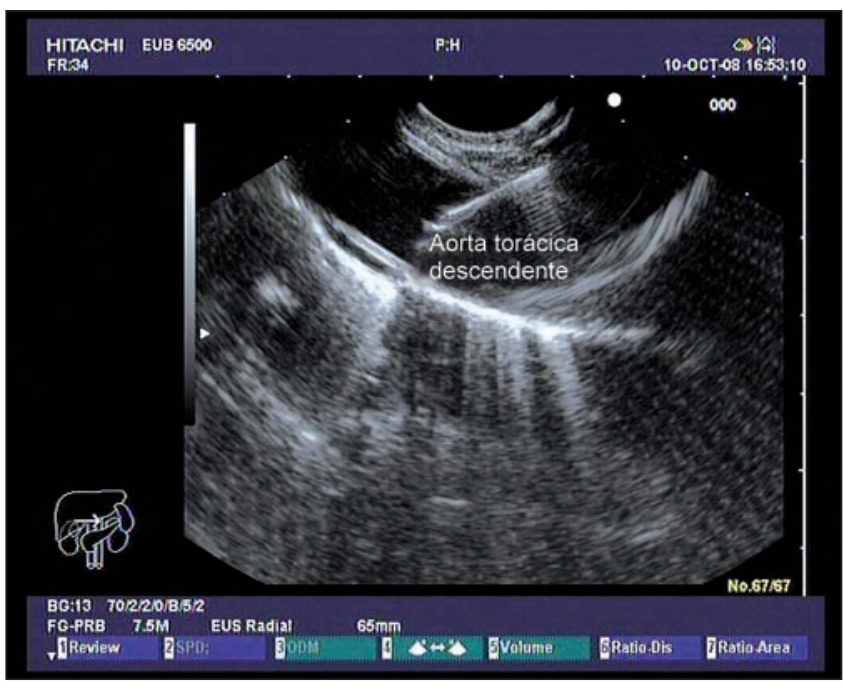

Fig. 4. Puncture of the descending thoracic aorta. Punción de aorta torácica descendente.

3. Hemodynamic behavior: hemodynamic stability was observed during the whole process with arterial pressure maintained and oxygen saturation within the normal range.

4. Possibility of infection: hemocultures were obtained immediately before and after each study in both animals, and were negative in both cases (Table I). No fever, loss of appetite or clinical deterioration were observed during the procedure, nor during the ten days of monitoring.

5. Response to puncture: both animals recovered normally from the anesthetic after the study, and stayed alive for 10 days without incident. The enzymatic markers for myocardial damage showed no significant alterations between baseline values and levels measured post-procedure, and between 10 days after the study and those obtained immediately after the procedure (Table I).

Table I. Laboratory test results

\begin{tabular}{|c|c|c|c|c|}
\hline Animal 001 & $\begin{array}{l}C K \\
(I U / L)\end{array}$ & $\begin{array}{l}\text { Myoglobin } \\
\text { (ng/mL) }\end{array}$ & $\begin{array}{l}\text { Tropo } \\
\text { (ng/mL) }\end{array}$ & $\begin{array}{l}C K-M B \\
\text { (ng/mL) }\end{array}$ \\
\hline $\begin{array}{l}\text { Basal } \\
\text { Postoperatory } \\
10 \text { days }\end{array}$ & $\begin{array}{c}576 \\
1,268 \\
1,229\end{array}$ & $\begin{array}{l}31.57 \\
31.31 \\
42.16\end{array}$ & $\begin{array}{l}0.01 \\
0.01 \\
0.01\end{array}$ & $\begin{array}{c}0.977 \\
1 \\
0.106\end{array}$ \\
\hline Animal 002 & $\begin{array}{l}C K \\
(I U / L)\end{array}$ & $\begin{array}{c}\text { Myoglobin } \\
\text { (ng/mL) }\end{array}$ & $\begin{array}{l}\text { Tropo } \\
\text { (ng/mL) }\end{array}$ & $\begin{array}{l}C K-M B \\
(n g / m L)\end{array}$ \\
\hline $\begin{array}{l}\text { Basal } \\
\text { Postoperatory } \\
10 \text { days }\end{array}$ & $\begin{array}{c}680 \\
1,386 \\
747\end{array}$ & $\begin{array}{c}21 \\
22.1 \\
21\end{array}$ & $\begin{array}{c}0.01 \\
0.051 \\
0.01\end{array}$ & $\begin{array}{l}1.15 \\
1.11 \\
0.1\end{array}$ \\
\hline
\end{tabular}

Hemocultures and enzyme markers of baseline myocardial damage, after the procedure and at 10 days. CK: creatin kinase; Tropo: troponin; CK-MB: creatin kinase specific to the myocardium.
-Echocardiographic study: in animal number 1, at the end of the study, after successive needle punctures a transitory image of an endothelial auricular 'flap' was observed with no hemodynamic repercussion. In animal number 2, after repeated puncturing of the interauricular partition, this was seen to thicken, corresponding to a small hematoma. After puncturing the descending thoracic aorta, similarly a small hematoma was observed in the media layer, though there was no evidence of an intimal 'flap' nor of the outer layer of the vessels' adventitia being broken.

-Study of the necropsy: this was performed by the veterinary staff from the Minimally Invasive Surgery Center Jesús Usón in Cáceres, who have more than 13 years' experience in research on animal models. After the macroscopic study samples were prepared for preservation. They were then studied by the teaching staff at Anatomy and Embryology Dept., Veterinary Faculty, University of Murcia.

Macroscopically, no lesions or effusions were observed, nor were there any significant adhesions. Subsequently, after the cardiopulmonary block had been fixed by dilatation and immersion, all cardiac structures were studied using stereoscopic magnification, paying special interest to punctured areas (LA, RA, thoracic aorta). In the interatrial septum a small area with hematoma was identified (Fig. 5). The histological study of this area indicated a minimal laceration of the endocardium in both atria.

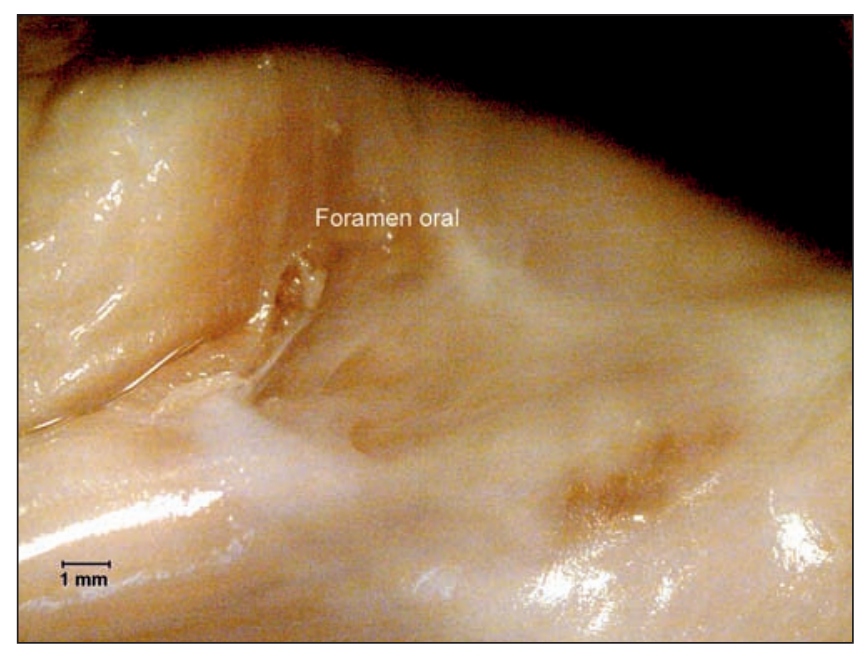

Fig. 5. Necropsy from the puncture of the oval foramen in the interauricular partition.

Hallazgo de necropsia de la punción del foramen oval en el tabique interauricular.

\section{DISCUSSION}

At present there is a design trend which favors the minimally invasive surgical approach. Thus, in the field of digestive endoscopy, transgastric endoscopic surgical 
applications through natural orifices (NOTES) are being developed (11), as are various angiographic approaches using EUS (12). Another experimental study has managed to successfully perform transesophageal access to the thoracic cavity and from there to the pericardium and epicardium, successfully closing the submucous access hole used (13). At the same time in cardiac surgery new techniques are being used such as valvuloplasty, ablation of anomalous vessels and of the auricular wall, as well as surgical techniques without aortic clamping $(14,15)$.

There are very few references available in the literature. The experiment described by Fritscher-Ravens et al. (8) is the only reference, to our knowledge, on this topic. This group studied eight experimental pigs in which they evaluated the effect of the introduction of cardiac puncture needles, thermal ablation of the myocardium and the mitral and aortic valves, and even coronary puncture on the heart. In all cases they were able to access the cardiac chambers, they did not register any hemodynamic alteration or arrhythmias during the intervention or after 2 weeks of observation, and the necroscopic study did not reveal any iatrogeny on the punctured cardiac structures. Similarly, they inform of three cases in humans in which the technique was used without complications: two drainages of a pericardial hemorrhage and an FNPA to study a lump in LA, which was in fact a clot. In the bibliography other isolated clinical cases have been published of pericardial drainages and pericardial and left auricle lesion punctures. They describe excellent results and no complications.

The present study has enabled us to evaluate accessibility to the heart from the esophagus using endoscopic ultrasonography, with results which are very similar to those in the literature, offering two innovations as yet not described: the puncture of the right auricle via the interauricular partition and of the descending thoracic aorta, in and easy and apparently safe manner.

After this study, a new form of accessing the cardiac cavities and large adjacent vessels can be envisaged. We believe that further studies on experimental animals are necessary to corroborate our findings and to enable the study of diagnostic and therapeutic possibilities of the technique in different models of the cardiac, pericardial and aortic pathology. However, our preliminary results support a more extensive use of ultrasound-guided endoscopy by gastroenterologists and cardiologists than for its current clinical applications, which are limited to the study of gastrointestinal organs and of mediastinal lesions secondary to pulmonary pathology.

\section{REFERENCES}

1. Ang TL. Endoscopic ultrasound: moving from diagnostics to therapeutics. J Dig Dis 2008; 9: 117-28.

2. Khul HP, Harta P. The impact of transesophageal echocardiography on faily clinical practice. Eur J Echocardiograf 2004; 5: 455-68.

3. Yamao K, Irisawa A, Inoue H, MatsudaK, Kida M, Ryozawa S, et al. Standard imaging techniques of endoscopic ultrasound-guided fineneedle aspiration using a curved linear array echoendoscope. Dig Endos 2007 19: 180-205.

4. Varas MJ, Miquel JM, Abad R, Espinos JC, Cañas MA, Fabra R, et al. Intervencionist endoscopic ultrasonography. A retrospective analysis of 60 procedures. Rev Esp Enferm Dig 2007; 99: 138-44.

5. Nazarian S, Kantsevoy SV, Zviman MM, Matsen FA 3rd, Calkins H, Berger RD, et al. Feasibility of endoscópica guidance for nonsurgical transthoracic atrial and ventricular epicardial ablation. Heart Rhythm 2008; 5: 1115-9.

6. Scholte AJ, Frissen PH, van der Wouw PA. Transesophageal echocardiolgraphy-guided transvesnous biopsy of an intracardiac tumor. Echocardiography 2004; 21: 721-3.

7. Nazarian S, Kantsevoy SV, Zviman MM, Matsen FA 3rd, Calkins H, Berger RD, et al. Feasibility of endoscopic guidance for nonsurgical transthoracic atrial andventricular epicardial ablation. Heart Rhythm 2008; 5: 1115-9

8. Fritscher-Ravens A, Ganbari A, Mosse CA, Swain P, Koehler P, Patel $\mathrm{K}$. Transesophageal endoscopic ultrasound-guided access to the heart. Endoscopy 2007; 39: 385-9.

9. Fritscher-Ravens A, Sriram PV, Bobrowski C, Pforte A, Topalidis T, Krause C, et al. Mediastinal lymphadenopathy in patients with and without previous malignancy: EUS-FNA based cytodiagnosis in 153 patients. AM J Gastroenterol 2000; 95: 2278-84.

10. García Fernández MA. Anatomía transesofágica: planos horizontales. En: Ecocardiografía Transesofágica. Ed. Interamericana, McGraw-Hill; 1991.

11. Fritscher-Ravens A, Patel K, Ghanbari A, Khale E, Von Herbay A, Fritscher T, et al. Natural orifice transluminal endoscopic surgery (NOTES) in the mediastinum: long-term survival animal experiments in transesophageal access, including minor surgical procedures. Endoscopy 2007; 39: 870-5.

12. Magno P, Ko CW, Buscaglia JM, Giday SA, Jagannath SB, Clarke $\mathrm{JO}$, et al. EUS-guided angiography: a novel approach to diagnostic and therapeutic interventions in the vascular system. Gastrointest Endosc 2007; 66: 587-91.

13. Sumiyama K, Gostout CJ, Rajan E, Bakken TA, Knipschield MA, Cheng S, et al. Pilot study of transesophageal endoscópica epicardial coagulation by submucosal endoscopy with the mucosal flap safety valve technique. Gastrointest Endosc 2008; 67: 497-501.

14. Loulmet DF, Patel NC, Jennings JM, Subramanian VA. Less invasive intracardiac surgery performed without aortic clamping. Ann Thorac Surg 2008; 85: 1551-5.

15. Yu R, Ma C, Dong J, Liu X, Kang J. Transeophageal high intensity focused ultrasound ablation of left atrium posterior wall: new method for treating atrial fibrillation. Med Hypotheses 2008; 70: 654-6. 


\title{
Acceso transesofágico a cavidades cardiacas y aorta torácica descendente mediante ecoendoscopia. Estudio experimental
}

\author{
A. López Martín, M. Pérez-Paredes ${ }^{1}$, P. Esteban, R. Latorre², F. Soria ${ }^{3}$, R. Lima ${ }^{3}$, I. Delgado ${ }^{3}$, \\ A. Ruiz $\operatorname{Ros}^{1}$, E. Pérez Cuadrado y L. F. Carballo Álvarez ${ }^{4}$
}

Secciones de Aparato Digestivo y ${ }^{\prime}$ Cardiología. Hospital Universitario Morales Meseguer. ${ }^{2}$ Facultad de Veterinaria. Universidad de Murcia. ${ }^{3}$ Centro de Cirugía de Mínima Invasión Jesús Usón (CCMI). Cáceres. ${ }^{4}$ Servicio de Digestivo. Hospital Virgen de la Arrixaca. Murcia

\section{RESUMEN}

Objetivo: las aplicaciones de la ultrasonografía endoscópica se han diversificado en los últimos tiempos. La posibilidad de acceder al territorio cardiaco se ha explorado en modelos experimentales con buenos resultados, abriendo un campo de nuevas posibilidades de intervencionismo diagnóstico y terapéutico hasta hace poco impensables. Los objetivos planteados en este trabajo pretenden evaluar la anatomía cardiaca, su abordaje, la seguridad del procedimiento experimental y los cambios morfológicos e histológicos derivados.

Material y métodos: se ha trabajado con dos animales adultos de la especie porcina a los que se han practicado diversos abordajes a cavidades cardiacas y aorta torácica descendente con excelentes resultados.

Resultados: se han identificado y abordado diversas estructuras cardiacas (aurícula derecha, aurícula izquierda, ventrículo izquierdo, válvulas cardiacas) y grandes vasos. El uso de contraste intracavitario y desde una vía venosa periférica ha permitido asegurar los espacios anatómicos estudiados. Durante los procedimientos se ha monitorizado la aparición de arritmias, el comportamiento hemodinámico, la posibilidad de infección mediante la obtención de hemocultivos antes y después de aquellos y la respuesta a las punciones.

Conclusiones: el presente trabajo nos ha permitido evaluar el acceso al corazón desde la luz esofágica mediante ultrasonografía endoscópica, con unos resultados muy similares a los observados en la literatura, ofreciendo dos novedades como la punción de la aurícula derecha a través del tabique interauricular y de la aorta torácica descendente, de forma fácil y aparentemente segura.

Palabras clave: Ecoendoscopia. Cavidades cardiacas. Punción con aguja fina. Estudio experimental.

\section{INTRODUCCIÓN}

La ultrasonografía endoscópica (USE) permite explorar con precisión el área situada entre 7 a $10 \mathrm{~cm}$ alrededor del tubo digestivo lo que incluye a nivel de mediastino las estructuras cardiacas de las que la aurícula izquierda y el tronco de la pulmonar son directamente accesibles. La USE con punción aspiración con aguja fina (USE-PAAF) se ha establecido como una técnica segura con una tasa de complicaciones muy baja, para diversas aplicaciones como la obtención de muestras de diversos tipos de lesiones, el drenaje de colecciones, la esclerosis de lesiones y la aplicación de fármacos, por lo que ha alcanzado una gran proyección más allá de la esfera gastroenterológica (1).

La relación anatómica del esófago con el corazón ha llevado al desarrollo de la ecocardiografía transesofágica ampliamente implantada en la práctica clínica pero cuando se plantean aplicaciones intervencionistas se hace necesario el uso de ecoendoscopios lineales (2-4).

Uno de los logros más importantes de la cardiología moderna es el poder llevar a cabo técnicas diagnósticas y terapéuticas que requieren un abordaje invasivo o quirúrgico, a través de procedimientos semiinvasivos de alto rendimiento clínico y que minimizan el potencial riesgo o daño al paciente. Numerosas técnicas en Cardiología se realizan a través de este tipo de abordaje, generalmente intravascular. Así, los estudios coronariográficos y hemodinámicos, la valvuloplastia, la biopsia miocárdica, el drenaje del derrame pericárdico o la ablación de vías accesorias por radiofrecuencia, son procedimientos rutinarios en este sentido (5-7). La posibilidad de adaptar nuevas tecnológicas en este campo y de explorar otras vías de aproximación a las cavidades cardiacas, distintas de la intraarterial e intravenosa, suponen un reto de gran interés clínico e investigador.

El abordaje ecoendoscópico y los procedimientos de punción aspiración con aguja fina están bien establecidos en lesiones digestivas y mediastínicas, habiéndose empleado tanto con fines diagnósticos como terapéuticos. Sin embargo, la posibilidad de abordar y alcanzar con agujas de PAAF las cavidades cardiacas y la aorta torácica no ha sido todavía bien estudiada, existiendo algunos casos clínicos aislados comunicados y una corta experiencia en el animal de experimentación, que ha informado de buenos resultados preliminares $(8,9)$. 
El objetivo de este estudio fue evaluar la viabilidad del abordaje de las cavidades cardiacas desde la aproximación esofágica, así como realizar estudios de seguridad de la técnica.

En el presente trabajo hemos analizado la viabilidad de acceso a las diferentes cavidades cardiacas a través de una punción transesofágica del corazón, la reactividad miocárdica a dicho procedimiento, los cambios morfológicos e histológicos de las estructuras puncionadas (pared esofágica, pericardio, pared de AI, tabique interauricular y pared de aorta torácica descendente) y el comportamiento hemodinámico durante los estudios.

\section{MATERIAL Y MÉTODOS}

Realizamos el estudio con 2 animales adultos de la especie porcina de $50 \mathrm{~kg}$ de peso sin patología conocida previa (animal 1 y 2). El estudio se llevó a cabo en el Centro de Cirugía de Mínima Invasión Jesús Usón de Cáceres. La preparación y monitorización anestésica corrió a cargo de veterinarios anestesiólogos del Centro.

Se procedió a asepsia cuidadosa de la cavidad oral y anestesia general tras intubación orotraqueal y conexión a ventilación mecánica. Se monitorizaron los animales con ECG continuo, pulsioximetría y tensión arterial. Todos los tiempos de trabajo se han registrado con dos sistemas de grabación simultáneos. Los animales tuvieron un ayuno previo de 24 horas.

Esta actividad ha sido aprobada por el Comité de Ética de Experimentación Animal del CCMJU y cumple la Directiva de la UE 86/609/CEE, de 26 de noviembre de 1986, sobre protección de animales utilizados para experimentación y otros fines científicos y docentes, que ha sido incorporada al ordenamiento jurídico español mediante el RD 223/1988, de 14/03, por la que se establecen las normas de los establecimientos de cría, suministradores y usuarios de animales de experimentación de titularidad estatal, así como las de autorización para el empleo de animales en experimentos, y el RD $1201 / 2005$, sobre protección de animales utilizados para experimentación y otros fines científicos.

Al Comité de Ética se le presenta una memoria detallada de la actividad con un protocolo de las intervenciones a realizar. Los animales están sometidos a anestesia inhalatoria, con control analgésico y monitorización completa. No se hizo ninguna recomendación por parte del Comité Ético.

1. Material instrumental y de ultrasonidos. Los procedimientos se han llevado a cabo con un fibroecoendoscopio lineal de Pentax modelo FG 32 UA con adaptador óptico para video, acoplado a una consola de ecografía Hitachi EUB 6500. Se han empleado agujas de punción de 19 y 22G de Cook, guías radiolúcidas y contraste ultrasonográfico Sonovue ${ }^{\circledR}$. Las intervenciones sólo se realizaron bajo control ecoendoscópico, con inyección de medio de contraste ecográfico para evidenciar determinados segmentos.

2. Procedimiento anestésico. Los animales son sometidos a una anestesia inhalatoria (Sevofluorano) con control analgésico intraoperatorio (Ketamina, ketorolaco, diazepam).

\section{Monitorización anestésica}

- Parámetros cardiacos y hemodinámicos: frecuencia cardiaca, electrocardiograma, presión arterial no invasiva.

- Parámetros ventilatorios: frecuencia respiratoria, pulsioximetría, presión en vías aéreas, volumen corriente y volumen minuto, $\mathrm{CO}_{2}$ inspirado y espirado, $\mathrm{O}_{2}$ inspirado y espirado, capnograma, pletismograma, sevofluorano inspirado y espirado.

Tras la recuperación de los animales estos fueron mantenidos durante 10 días en sus cubículos individuales. Durante la hospitalización los animales son sometidos a control diario por parte del personal veterinario responsable (control del apetito, toma de la temperatura, auscultación).

Transcurrido este periodo de seguimiento los animales son eutanasiados y se les practica una necropsia, donde se evalúan las lesiones macroscópicas en cavidad torácica y se envían las muestras de las vísceras para su estudio microscópico.

3. Estudio analítico. Con el objeto de determinar la posible iatrogenia sobre el músculo cardiaco, así como la posibilidad de infección se determinaron antes y después del procedimiento, así como a los 10 días los siguientes parámetros: hemocultivos, $(\mathrm{CK}$, mioglobina, troponina $\mathrm{T}$, CK-MB) CPK-mb, troponina I, miosina, hemograma y bioquímica general.

4. Estudio ecoendoscópico. El procedimiento se inició con la introducción del ecoendoscopio lineal por vía oral identificando en primer lugar de forma detallada el área mediastínica y estructuras vasculares previas a la valoración de la anatomía cardiaca del animal. A continuación, se abordaron las estructuras cardiacas desde la aproximación transesofágica con planos estándar descritos para sondas monoplano (10) entrando en el corazón a través de la AI. Las estructuras anatómicas más próximas al esófago son la AI, las válvulas aórtica y mitral y el tronco de la arteria pulmonar. Las cavidades cardiacas derechas quedan en un plano más distal. La administración de contraste para ultrasonidos (Sonovue $\left.{ }^{\circledR}\right)$ tanto a través de la aguja de punción como desde una vía venosa periférica permitió demostrar la entrada de la aguja en cada cavidad y asegurar de forma precisa su identificación. Tras avanzar el ecoendoscopio por el esófago entre 30 y $45 \mathrm{~cm}$, las agujas de punción fueron introducidas a través de la AI en el VI haciendo avanzar mediante la de 19G un hilo guía hasta AI y por la válvula mitral a VI (animal número 1) y acceder a la AD atravesando el tabique interauricular así como la pared de la aorta torácica descendente (animal número 2). 


\section{RESULTADOS}

El control de las alteraciones hemodinámicas intraoperatorias fue llevado a cabo por el coordinador de la Unidad de Anestesiología, Reanimación y Terapéutica del Dolor, veterinario con más de 15 años de experiencia en investigación en modelo animal y doctorado por la Universidad de Extremadura, con una tesis en modelo porcino referente al control analgésico intraoperatorio, siendo miembro fundador de la asociación española de anestesiología veterinaria. Además de contar en el mismo quirófano con un especialista en cardiología humana.

\section{Principales hallazgos}

- Animal número 1: se identificaron las diferentes estructuras cardiacas visualizándolas en los planos ecocardiográficos correspondientes a los cortes longitudinales de cavidades derechas y de cavidades izquierdas con tracto de salida de VI y válvula aórtica (Figs. 1 y 2). La estructura más cercana y fácilmente abordable desde el esófago fue la AI. Se procedió a la punción de la AI con distintas angulaciones buscando el eje más longitudinal que permitiera el avance de la aguja hacia el ventrículo izquierdo a través de la válvula mitral, circunstancia que se consiguió de modo eficaz (Fig. 3).

- Animal número 2: igualmente se identificó la anatomía cardiaca normal y se procedió al abordaje de la $\mathrm{AD}$ a través del tabique interauricular una vez alcanzada la AI desde el esófago adyacente, utilizando un plano transversal de raíz de aorta con AI, AD y septum interauricular (Fig. 4). No hubo dificultad en llegar hasta la AD, aunque hubo que realizar punciones repetidas del tabique en un intento de acceder a través de la fosa oval. Desde la sección de la raíz de la aorta se giró el endoscopio en sentido antihorario hasta registrar un corte horizontal de la aorta descendente, procediéndose a la punción de dicho vaso en diferentes puntos (Fig. 5).

2. Inducción de arritmias: durante los estudios no se registraron arritmias, salvo escasas extrasístoles ventriculares aisladas sin formas complejas, ante el contacto de la aguja con el miocardio del ventrículo izquierdo.

3. Comportamiento hemodinámico: durante todo el procedimiento se observó estabilidad hemodinámica con tensiones arteriales mantenidas y saturación de oxígeno en rango normal.

4. Posibilidad de infección: se obtuvieron hemocultivos antes y justo al final de cada estudio en ambos animales, siendo negativos en los dos casos (Tabla I). No se observó fiebre, pérdida de apetito o deterioro clínico durante el procedimiento ni en los diez días de seguimiento.

5. Respuesta a la punción: ambos animales tuvieron una recuperación anestésica normal tras el estudio y se mantuvieron vivos sin incidencias clínicas durante diez días. Los marcadores enzimáticos de daño miocárdico no mostraron alteraciones significativas entre los valores basales, posprocedimiento y a los 10 días del estudio y los obtenidos inmediatamente después de terminado el procedimiento (Tabla I).

Tabla I. Resultados analíticos

\begin{tabular}{|c|c|c|c|c|}
\hline Animal 001 & $\begin{array}{l}C K \\
(i u / l)\end{array}$ & $\begin{array}{c}\text { Mioglobina } \\
(\mathrm{ng} / \mathrm{ml})\end{array}$ & $\begin{array}{l}\text { Tropo } \\
\text { (ng/ml) }\end{array}$ & $\begin{array}{l}C K-M B \\
(\mathrm{ng} / \mathrm{ml})\end{array}$ \\
\hline Basal & 576 & 31,57 & 0,01 & 0,977 \\
\hline Postoperatorio & 1.268 & 31,31 & 0,01 & 1 \\
\hline 10 días & 1.229 & 42,16 & 0.01 & 0,106 \\
\hline Animal 002 & $\begin{array}{l}C K \\
(i u / l)\end{array}$ & $\begin{array}{c}\text { Mioglobina } \\
(\mathrm{ng} / \mathrm{ml})\end{array}$ & $\begin{array}{l}\text { Tropo } \\
\text { (ng/m/) }\end{array}$ & $\begin{array}{l}C K-M B \\
(\mathrm{ng} / \mathrm{ml})\end{array}$ \\
\hline Basal & 680 & 21 & 0,01 & 1,15 \\
\hline Postoperatorio & 1.386 & 22,1 & 0,051 & 1,11 \\
\hline 10 días & 747 & 21 & 0,01 & 0,1 \\
\hline
\end{tabular}

Hemocultivos y marcadores enzimáticos de daño miocárdico basales, tras el procedimiento y a los 10 días. CK: creatin kinasa; Tropo: troponina; CK-MB: creatin kinasa específica de miocardio.

- Estudio ecocardiográfico: en el animal número 1, se observó al final del estudio, tras sucesivas punciones de la aguja, una imagen transitoria de "flap" auricular endotelial sin repercusión hemodinámica. En el animal número 2 tras la punción repetida del tabique interauricular se observó un engrosamiento del mismo correspondiente a un pequeño hematoma. Tras la punción en aorta torácica descendente su visualizó igualmente un pequeño hematoma en la capa media sin evidencia de "flap" intimal ni de rotura de la capa externa o adventicia del vaso.

- Estudio de las piezas de necropsia: fue llevada a cabo por personal veterinario del Centro de Cirugía de Mínima Invasión de Cáceres, con más de 13 años de experiencia en Investigación en modelo animal. Posteriormente del estudio macroscópico las muestras son preparadas para su conservación y fueron estudiadas en la cátedra de Anatomía y Embriología de la Facultad de Veterinaria de Murcia, por parte de personal docente de esta Unidad.

Macroscópicamente no se apreció ninguna lesión ni efusiones, ni adherencias significativas. Posteriormente, tras realizar una fijación por dilatación e inmersión del bloque cardiopulmonar, se estudiaron mediante lupa estereoscópica todas las estructuras cardiacas prestando especial interés a los lugares de punción (AI, $\mathrm{AD}$, aorta torácica). En el septo interatrial se identificó una pequeña zona con hematoma (Fig. 5). El estudio histológico de dicha zona indicó mínima laceración del endocardio en ambos atrios.

\section{DISCUSIÓN}

En la actualidad existe una corriente de diseño orientada al abordaje quirúrgico mínimamente invasivo. Así, en el campo de la endoscopia digestiva se están desarrollando aplicaciones de cirugía endoscópica transgástrica a 
través de orificios naturales (NOTES) (11) y diversos abordajes de angiografía mediante USE (12). Otro estudio experimental ha conseguido realizar con éxito el acceso endoscópico transesofágico a la cavidad torácica y desde aquí a pericardio y epicardio, pudiendo cerrar el orificio de paso submucoso empleado (13). A su vez la cirugía cardiaca está poniendo en práctica nuevas técnicas de valvuloplastia, ablación de vías anómalas y de pared auricular así como técnicas quirúrgicas sin clampaje aórtico $(14,15)$.

Existen muy pocas referencias disponibles en la literatura. La experiencia aportada por Fritscher-Ravens y cols. (8) constituye la única referencia, en nuestro conocimiento, sobre este tema. Así, este grupo estudió ocho cerdos de experimentación en los que se evaluó el efecto sobre el corazón de la introducción de las agujas de punción cardiaca, la ablación termal del miocardio y las válvulas mitral y aórtica, e incluso la punción coronaria. En todos los casos se pudo acceder a las cámaras cardiacas, no se registraron alteraciones hemodinámicas ni arritmias durante la intervención ni tras 2 semanas de observación y en el estudio necrópsico no se informó de iatrogenia sobre las estructuras cardiacas puncionadas. Igualmente, informan sobre tres casos en humanos en los que se aplicó la técnica sin complicaciones: dos drenajes de derrame pericárdico y una PAAF para estudio de una masa en $\mathrm{AI}$, que resultó ser un trombo. En la literatura existen otros casos clínicos aislados publicados de drenaje pericárdico y punción de lesiones de pericardio y de aurícula izquierda con excelentes resultados y ausencia de complicaciones.

El presente trabajo nos ha permitido evaluar la accesibilidad al corazón desde la aproximación esofágica mediante ultrasonografía endoscópica, con unos resultados muy similares a los obtenidos en la literatura, ofreciendo dos novedades hasta ahora no descritas como la punción de la aurícula derecha a través del tabique interauricular y de la aorta torácica descendente, de forma fácil y aparentemente segura.

Tras este estudio es posible evidenciar una nueva vía de acceso a las cavidades cardiacas y grandes vasos adyacentes. Aunque consideramos que hacen falta nuevos estudios en el animal de experimentación que corroboren nuestros hallazgos y que permitan estudiar las posibilidades diagnósticas y terapéuticas de la técnica en diferentes modelos de patológica cardiaca, pericárdica y aórtica, nuestros resultados preliminares apoyan el uso de la endoscopia guiada por ultrasonidos por digestólogos y cardiólogos, más allá de sus actuales aplicaciones clínicas limitadas al estudio de los órganos gastrointestinales y de lesiones mediastínicas secundarias a patología pulmonar. 